ISSN 2078-6441. Вісник Львівського університету. Серія географічна. 2013. Випуск 44. С. 99-113. Visnyk of the Lviv University. Series Geography. 2013. Issue 44. P. 99-113.

551.8:551.791:631.4

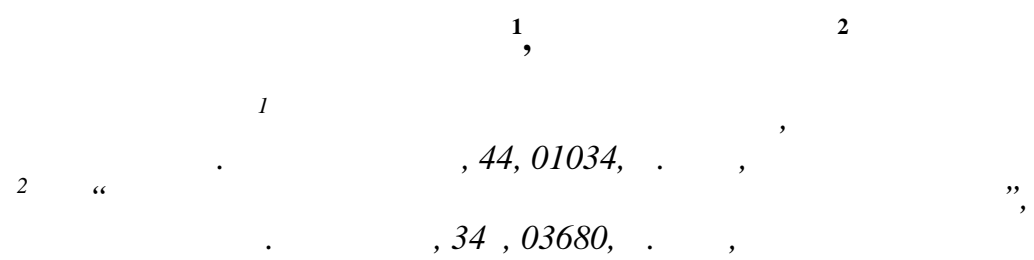

ведено д ні щодо вмісту орг нічних речовин т к рбон тів у викопних плейстоценових грунт $\mathrm{x}$ i лес $\mathrm{x}$ чотирьох нових розрізів четвертинних відкл дів н території ереднього обужжя. 'ясов но зн чення досліджень вмісту і розподілу гумусу т к рбон тів у різновікових горизонт х четвертинних відкл дів для п леогеогр фічних реконструкцій природних умов ч су формув ння викопних плейстоценових грунтів і лесів.

лючові слов : п леогеогр фія, плейстоцен, викопні грунти, леси, орг нічні речовини, к рбон ти.

ізним генетичним тип м суч сних грунтів, які формуються в певних фізикогеогр фічних умов х, вл стиві конкретні особливості будови, у тому числі вмісту й розподілу орг нічних речовин і к рбон тів. е дє змогу, вр ховуючи принцип кту лізму, використовув ти інформ цію про певні речовини, що містяться у викопних грунт х, під ч с п леогеогр фічних реконструкцій.

ослідженню орг нічних речовин у викопних грунт х присвячен зн чн кількість пр ць. ізні спекти цього пит ння розгляд ли . л зовськ , . луш нков , обродєєв, . рупеніков, . д нов, . юрменко, . к ідзе, . едлецький, . еличко, . еклич, . іренко, . твіїшин, . юрін, . юрін, . ич гов . ерг чев, . икін т ін.

ит ння к рбон тності плейстоценових відкл дів висвітлені у пр цях . исоцького, . боких, . рокос , . околовського, . морія, . орозов , . рігер, . риня, . еличк, . еклич т ін.

ет дослідження - окреслити зн чення д них щодо вмісту й розподілу гумусу i к рбон тів у четвертинних відкл д х (суч сних i викопних грунт х, лес х) для п леогеогр фічних реконструкцій природних умов ч су їхнього формув ння.

ослідження гумусових скл дових у викопних грунт х, ст новить безсумнівну п леогеогр фічну цінність, оскільки викопні грунти є своєрідними п м'ятник ми фізико-геогр фічних умов минулого т кінцевим результ том конкретного трив лого ет пу грунтоутворення. одноч с, кількісні пок зники вмісту гумусу у викопних грунт х свідч ть про інтенсивність т співвідношення процесів грунтоутворення $\mathrm{i}$ седимент ції.

відміну від суч сних грунтів, вміст гумусу у викопних плейстоценових грунт х, н віть в інтенсивно з б рвлених у сірий чи темний колір, невеликий i, з звич й, не

(C) орошкевич ., двернюк ., 2013 
перевищує $1 \%$. огляду н це пост є пит ння: чи не втр ч є гумус у фосилізов них викопних грунт х повністю своїх вл стивостей ун слідок ді генетичних перетворень? ні численних досліджень з свідчують, що хоч кількісні пок зники вмісту гумусу у викопних грунт х і змінюються, проте співвідношення кількісного скл ду т $\mathrm{x}$ р ктеру будови зберіг ються як 3 генетичними тип ми грунтів, т к і 3 їхніми профілями $[1,2,4,5,11$ т ін.]. окрем , подібні до суч сних грунтів 3 кономірності щодо зміни кількісного скл ду гумусу по профілю простежуються в чорноземоподібних і підзолистих грунт х. перших вміст гумусу зменшується поступово з глибиною,

в других - фіксують різке зменшення пок зників вмісту гумусу, спостеріг ють його перерозподіл по профілю. ч сом гумус, звич йно ж, з зн є не тільки кількісних, і якісних змін: зменшується його відсотковий вміст (ун слідок ч сткової мінер ліз ції т підвищення міцності зв'язків з мінер льною ч стиною грунту), збільшується відносний вміст гумінів [11 т ін.]. роте ці процеси не є н дмірною перешкодою для п леогеогр фічних реконструкцій. гідно 3 . екличем т . іренко [11, с. 161-162], плейстоценові грунтові утворення, з звич й, н леж ть до першої, рідше другої ст дій фосиліз ції відкл дів, які порівняно добре зберіг ють первинні озн ки д вніх грунтів.

основі п леогеогр фічних інтерпрет цій д них щодо орг нічних т інших речовин, окрім принципу кту лізму (будь-який теоретично можливий процес, що існує в суч сній природі, міг відбув тися в різні геологічні проміжки ч су), є принципи системності (кожен об'єкт природи є скл дною і с модост тньою системою), зон льності (кількісні, якісні т просторові пок зники природних компонентів у геогр фічній оболонці з леж ть від б л нсу тепл і вологи т змінюються в н прямі від полюсів до екв тор ), синхронності (періодичні зміни одних явищ і процесів відбув ються одноч сно $з$ іншими), н прямленості т ритмічності (природ $\mathrm{H}$ пл неті розвив ється під впливом ритмічних і н прямлених змін) [4, с. 32-38], шо д ють змогу використовув ти в п леогеогр фічних реконструкціях кількісні т якісні особливості орг нічних речовин у викопних грунт х.

орівняно з іншими п леогеогр фічними метод ми дослідження гумусових речовин м є т кі перев ги [5]: 1) орг нічні речовини постійно н явні у плейстоценових відкл д $\mathrm{x}$, як у генетичних горизонт х викопних грунтів, т к i в інших горизонт $\mathrm{x}$ негрунтових відкл дів, що д є змогу реконструюв ти умови утворення відкл дів т грунтів у розріз х, у яких нем є пилку, спор т ф уністичних з лишків; 2) орг нічні речовини в профілях добре збережених викопних грунтів з генетичними горизонт ми точно сформув лися in situ; вони не перевідкл дені т ідентифікують умови формув ння грунту н визн ченому елементі рельєфу.

2008 р. під ч с комплексної п леогеогр фічної експедиції нституту геогр фії кр їни . орошкевич, спільно із д-ром геогр. н ук . твіїшиною т к нд. геогр. н ук - рм зиненком провели п леопедологічні дослідження низки нових розрізів четвертинних відкл дів н території ереднього обужжя з відбором зр зків н різні види н лізів [10].

ході п леопедологічних досліджень нових розрізів визн чено їхнє суч сне геоморфологічне положення, викон но розчленув ння товщ четвертинних відкл дів згідно зі стр тигр фічною схемою кр їни [12], проведено п леопедологічні дослідження, які передб ч ли створення польових м сшт бних з рисовок розрізів 3 прим зК ми н тур льного м тері лу, дет льний м кроморфологічний опис відкл дів і відбір зр зків н різні види н лізів. л бор торних умов х із відібр них зр зків виготовлено шліфи з непорушеною структурою відкл дів, які про н лізов ні під мікроскопом для 
виявлення ді гностичних озн к первинних грунтоутворюв льних процесів 3 метою уточнення генезису викопних плейстоценових грунтів т їхньої генетичної ідентифік ції. езульт ти п леопедологічних (у тому числі мікроморфологічних) досліджень викопних плейстоценових грунтів ст ли основою для реконструкцій змін природних умов н території ереднього обужжя [7].

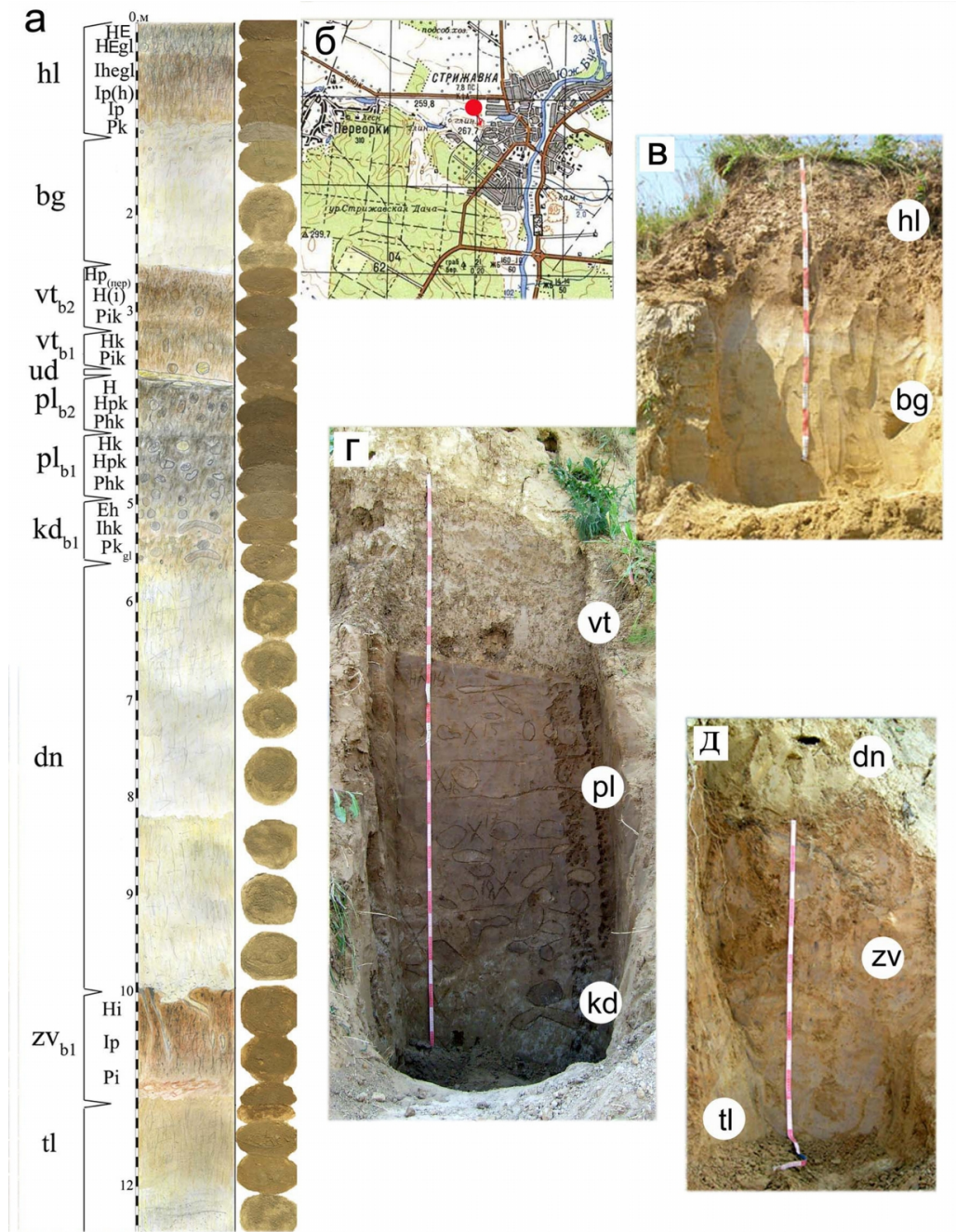

ис. 1. тр тигр фічне розчленув ння і польов м сшт бн з рисовк розрізу біля с. триж вк з прим зк ми н тур льного м тері луз . твї̈шиною ( ), місце розт шув ння розрізу (б), фото розчисток з індекс ми стр тигр фічних горизонтів (в-д).

еред досліджених розрізів були т кож розрізи біля с. триж вк (рис. 1) т c. йгород (див. рис. 2) інницької обл. окрем, у розрізі біля с. триж вк досліджено [9]: суч сний світло-сірий опідзолений оглеєний грунт (hl); типові бузькі леси (bg); дв викопні грунти вит чівського віку - темно-бурий р ннього оптимумy $\left(\mathrm{vt}_{\mathrm{b} 1}\right) \mathrm{T}$ бурий грунт пізнього $\left(\mathrm{vt}_{\mathrm{b} 2}\right)$; уд йські лесоподібні суглинки (ud); дв викопні 
грунти прилуцької світи - лучно-чорноземний грунт оптимуму $\left(\mathrm{pl}_{\mathrm{b} 1}\right)$ т чорнозем буроземоподібний пізнього $\left(\mathrm{pl}_{\mathrm{b} 2}\right) ; \mathrm{k}$ йд цький бурий лісовий опідзолений грунт $\left(\mathrm{kd}_{\mathrm{b} 1}\right)$; дніпровські лесоподібні суглинки місцями сильно опіщ нені $(\mathrm{dn}) ; \quad 3$ в дівський коричнево-бурий люві льний грунт $\left(\mathrm{zv}_{\mathrm{b} 1}\right)$; тилігульські лесоподібні суглинки сильно опіщ нені (tl).
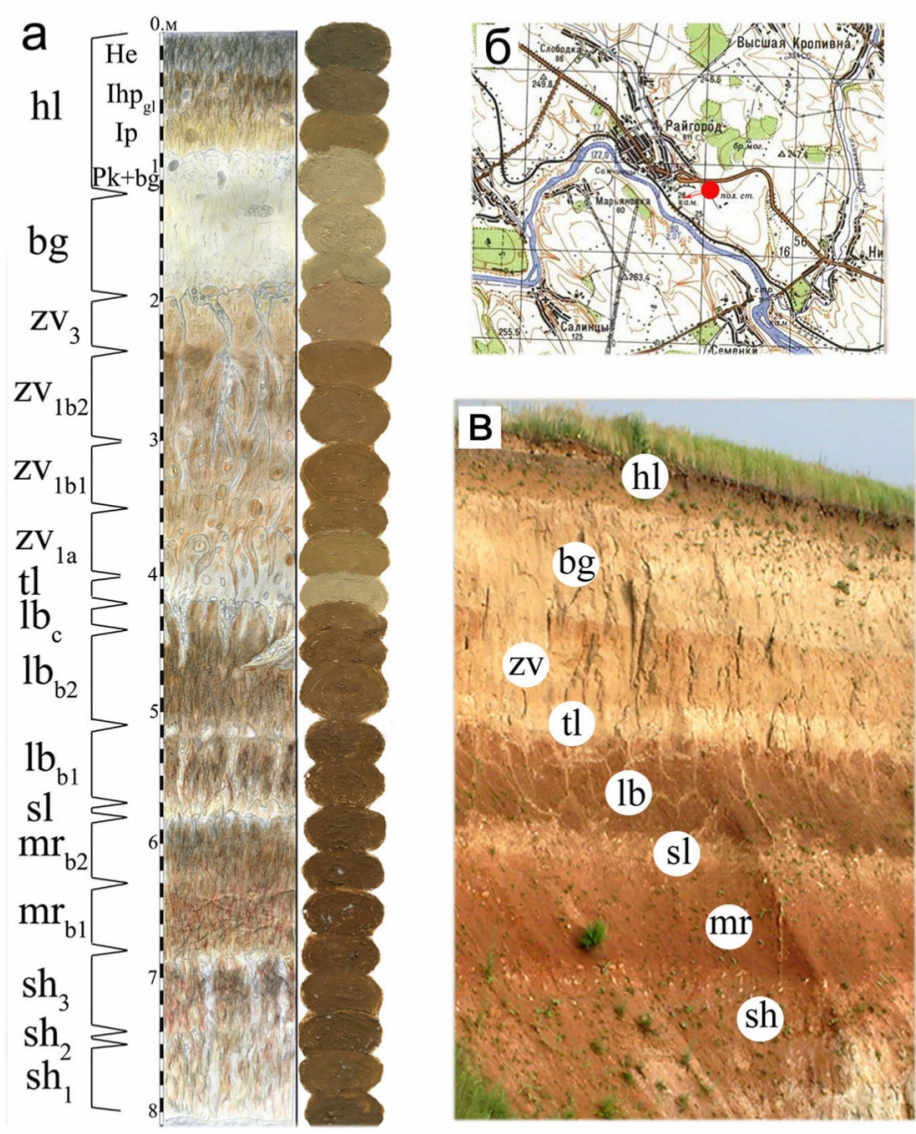

ис. 2. тр тигр фічне розчленув ння і польов м сшт бн з рисовк розрізу біля с. йгород з прим зК ми н тур льного м тері лу ( ), місцерозт шув ння розрізу (б),

фото розчистки з індекс ми стр тигр фічних горизонтів (в).

розрізі четвертинних відкл дів біля с. йгород досліджено [6]: суч сний темносірий опідзолений грунт (hl); типові бузькі леси (bg); чотири викопні грунти з в дівської світи - жовтув то-бурий лісовий поч ткової ст дії $\left(\mathrm{zv}_{\mathrm{a}}\right)$, червонув то-бурий лісовий $\mathrm{p}$ ннього оптимуму $\left(\mathrm{zv}_{1 \mathrm{~b} 1}\right)$, коричнюв то-бурий пізнього оптимуму $\left(\mathrm{zv}_{1 \mathrm{~b} 2}\right)$ т червонув то-бурий з верш льної ст дії $\left(\mathrm{zv}_{3}\right)$; тилігульські лесоподібні суглинки (tl); три викопні грунти лубенської світи - світло-коричнево-бурий лісовий р ннього оптимуму $\left(\mathrm{lb}_{\mathrm{b} 1}\right)$, бурув то-коричневий пізнього $\left(\mathrm{lb}_{\mathrm{b} 2}\right)$ т грунтові відкл ди з верш льної ст дії $\left(\mathrm{lb}_{\mathrm{c}}\right)$; сульські лесоподібні суглинки $(\mathrm{sl})$; дв грунти м ртоноської світи червонув то-бурий лучний $\mathrm{p}$ ннього оптимуму $\left(\mathrm{mr}_{\mathrm{b} 1}\right)$ т коричнюв то-бурий пізнього $\left(\mathrm{mr}_{\mathrm{b} 2}\right)$; широкинські червонув то-коричневі лучні грунти (sh). 
подібною схемою досліджень . орошкевич с мостійно вивчив розрізи біля с. езіменне (рис. 3) озятинського р-ну інницької обл. т біля м. м нь (див. рис. 4).

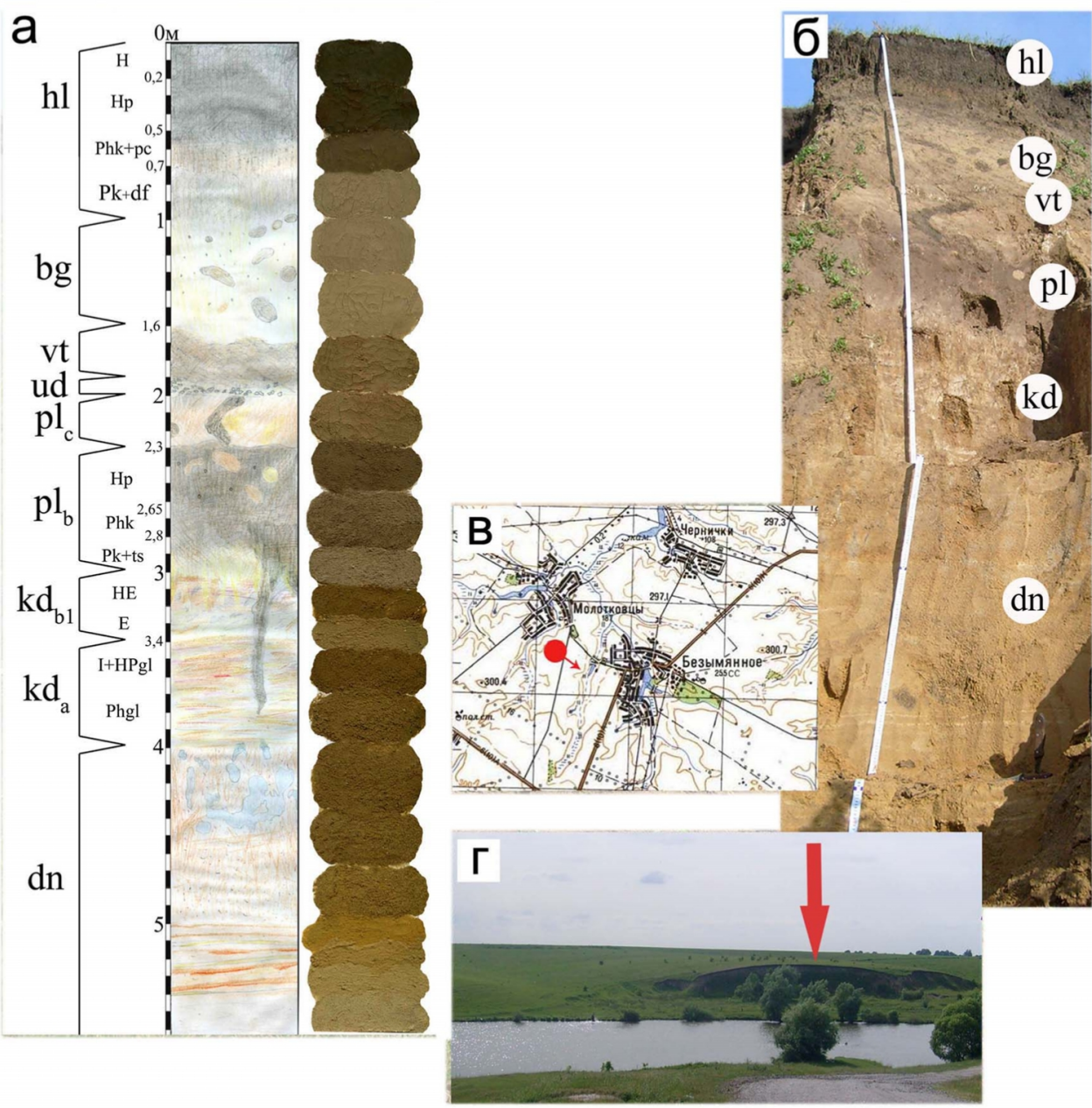

ис. 3. тр тигр фічне розчленув ння і м сшт бн польов з рисовк розрізу

біля с. езіменне з прим зк ми н тур льного м тері лу ( ), фото розчистки з індекс ми стр тигр фічних горизонтів (б), місце розт шув ння розрізу $(6,2)$.

підсумку, в розрізі біля с. езіменне ідентифіков но т кі типи грунтів: суч сний грунт - чорнозем вилугув ний (hl); реліктовий дофінівський дерновий грунт (df), який одноч сно є $\mathrm{Pk}$ горизонтом суч сного грунту; буроземоподібний викопний грунт вит чівського ч су (vt); дв грунти прилуцького ч су - лучно-чорноземний грунт оптимуму $\left(\mathrm{pl}_{\mathrm{b}}\right)$ т сірув то-бурий $з$ верш льної ст дії $\left(\mathrm{pl}_{\mathrm{c}}\right)$; дв грунти к йд цького ч су - дерново-глейовий поч ткової ст дії $\left(\mathrm{kd}_{\mathrm{a}}\right)$ т дерново-підзолистий грунт оптимуму $\left(\mathrm{kd}_{\mathrm{b} 1}\right)$. розрізі т кож досліджено змінені процес ми суч сного грунтоутворення причорноморські лесоподібні суглинки (pc), бузькі (bg) т уд йські (ud) лесоподібні 
суглинки, з лишки тясминських лесів (ts), т кож дніпровські (dn) флювіо- т лімногляці льні піски, супіски, суглинки і глини.

розрізі біля м. м нь досліджено: суч сний чорнозем опідзолений (hl) т н гром джений н ньому в процесі к р’єрних робіт гумусовий ш $\mathrm{p}\left(\mathrm{hl}_{\mathrm{rex.}}\right)$; причорноморські лесоподібні суглинки (рc); дв викопні грунти дофінівської світи - чорноземоподібний грунт оптимуму $\left(\mathrm{df}_{\mathrm{b}}\right)$ т п лево-бурий степовий з верш льної ст дії $\left(\mathrm{df}_{\mathrm{c}}\right)$; бузькі типові леси (bg).
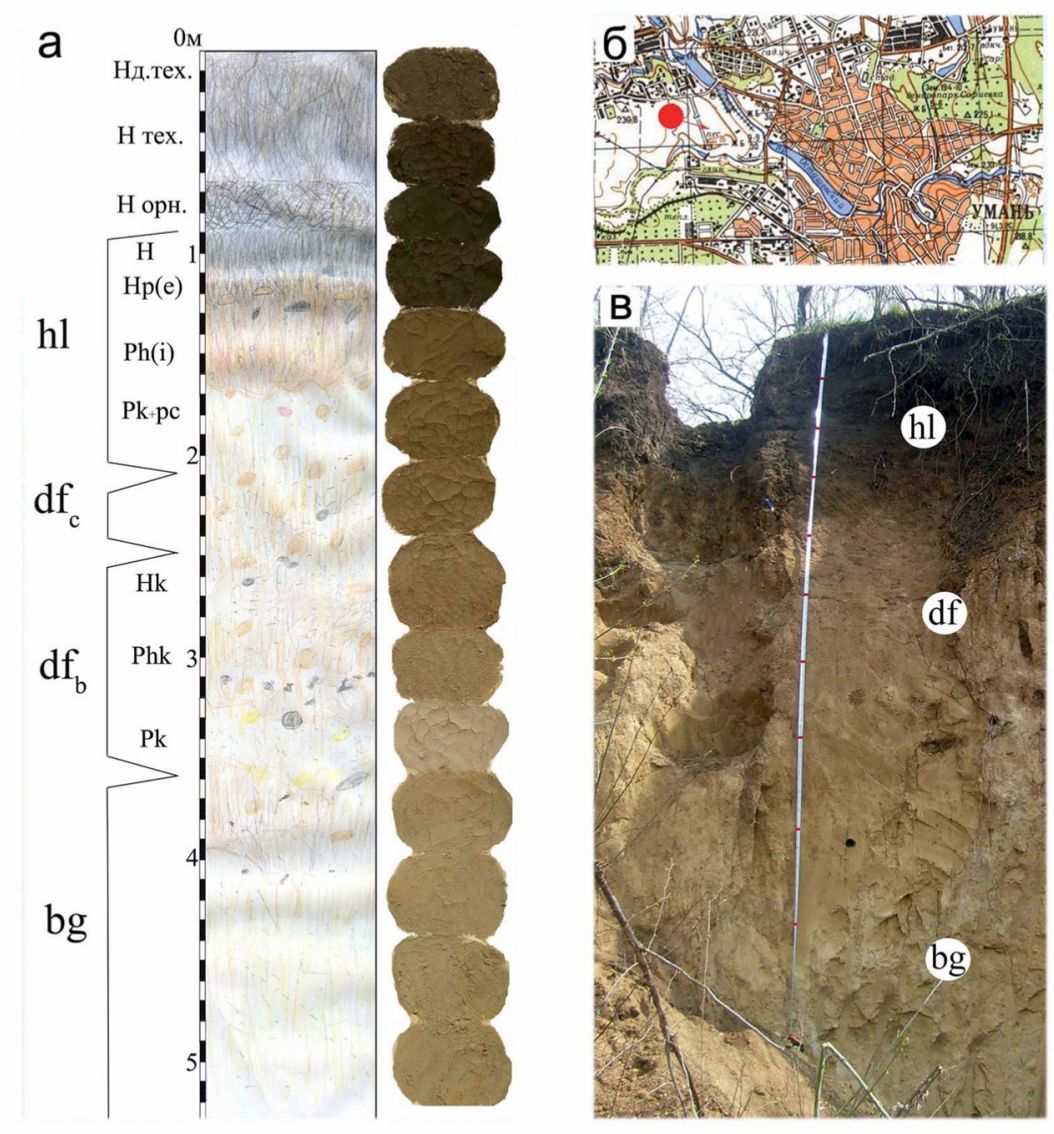

ис. 4. сшт бн польов 3 рисовк розрізу четвертинних відкл дів біля м. м нь зі стр тигр фічним розчленув нням відкл дів т прим зК ми н тур льного м тері лу ( ), місце розт шув ння розрізу (б), фоток ртк розчистки з індекс ми стр тигр фічних горизонтів (в).

ля отрим ння достовірнішої інформ ції щодо природних умов ч су утворення четвертинних відкл дів н території ереднього обужжя визн чено вміст гумусу і к рбон тів у 64 зр зк х з різновікових горизонтів чотирьох розрізів четвертинних відкл дів біля с. триж вк, с. йгород, м. м нь і с. езіменне. изн чення вмісту гумусу і к рбон тів проведене в л бор торії “нститут геохімії н вколишнього середовищ кр їни”. ля визн чення орг проведено дек рбоніз цію відкл дів (зр зки оброблено $10 \%$ розчином соляної кислоти). отім ці зр зки промито до 
нейтр льного середовищ i висушено 3 темпер тури $105-120^{\circ}$. природних i дек рбонізов них зр зК х визн чено вміст вуглецю з допомогою експрес- н ліз тор вуглецю АН-7529. міст гумусу обчислено множенням зн чення орг (у дек рбонізов них зр зК х) н коефіцієнт 1,724 [3]. трим ні н літичні результ ти н ведені у т бл. 1-4.

блиця 1 міст гумусу т к рбон тів у різновікових відкл д х розрізу триж вк

\begin{tabular}{|c|c|c|c|c|c|c|c|c|c|c|c|c|c|c|}
\hline тр тигр фічні & \multicolumn{5}{|c|}{ hl } & \multirow[t]{2}{*}{ bg } & \multirow[t]{2}{*}{$\mathrm{vt}_{\mathrm{b} 2}$} & \multirow[t]{2}{*}{$\mathbf{v t}_{\mathrm{b} 1}$} & \multirow[t]{2}{*}{$\mathbf{p l}_{\mathbf{b} 2}$} & \multirow[t]{2}{*}{$\mathbf{p l}_{\mathbf{b} \mathbf{1}}$} & \multirow[t]{2}{*}{$\mathbf{k d}_{\mathrm{b} 1}$} & \multirow[t]{2}{*}{ dn } & \multirow[t]{2}{*}{$\mathbf{z V}_{\mathbf{b} 1}$} & \multirow[t]{2}{*}{ tl } \\
\hline енетичні горизонти & $\mathrm{HE}$ & Hegl & Ihegl & Iph & $\mathrm{Pk}$ & & & & & & & & & \\
\hline либин , м & $\frac{n}{0}$ & 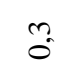 & $\because$ & $\stackrel{\infty}{0}$ & $\stackrel{\simeq}{-}$ & $\stackrel{n}{-}$ & $\stackrel{\infty}{i}$ & $\stackrel{\oplus}{m}$ & ले & $\stackrel{n}{f}$ & ñ & $\stackrel{\infty}{a}$ & $\hat{0}$ & $\stackrel{+}{\Xi}$ \\
\hline міст гумусу, \% & $\hat{\sigma}$ & กี & $\tilde{n}^{n}$ & $\stackrel{\Delta}{0}$ & $\stackrel{n}{\mathscr{f}}$ & $\tilde{m}_{0}$ & $\frac{9}{0}$ & $\frac{n}{0}$ & $n^{n}$ & है & $\frac{ \pm}{0}$ & $=$ & $\overrightarrow{0}$ & to \\
\hline міст к рбон тів, \% & n. & $\overline{0}$ & $\frac{m}{0}$ & テे & \begin{tabular}{l}
0 \\
\hdashline \\
+
\end{tabular} & $n$ & $\stackrel{\infty}{\sim}$ & $\hat{0}$ & $\stackrel{\infty}{0}$ & $\tilde{\pi}$ & $\stackrel{8}{0}$ & సે & $\stackrel{0}{0}$ & $\sigma_{0}^{0}$ \\
\hline
\end{tabular}

міст гумусу т к рбон тів у різновікових відкл д х розрізу йгород

\begin{tabular}{|c|c|c|c|c|c|c|c|c|c|c|c|c|c|c|c|}
\hline $\begin{array}{c}\text { тр тигр - } \\
\text { фічні }\end{array}$ & \multicolumn{4}{|c|}{ hl } & \multirow[t]{2}{*}{ bg } & \multirow[t]{2}{*}{$\mathbf{z v}_{3}$} & \multirow[t]{2}{*}{$\mathbf{Z v}_{\mathbf{1 b 2}}$} & \multirow[t]{2}{*}{$\mathbf{z v}_{\mathbf{1 b} \mathbf{1}}$} & \multirow[t]{2}{*}{$\mathbf{z v}_{\mathbf{1 a}}$} & \multirow[t]{2}{*}{ tl } & \multirow[t]{2}{*}{$\mathbf{l b}_{\mathrm{b} 2}$} & \multirow[t]{2}{*}{$\mathbf{l b}_{\mathrm{b} 1}$} & \multirow[t]{2}{*}{$\mathbf{m r}_{\mathbf{b} 2}$} & \multirow[t]{2}{*}{$\mathbf{m r}_{\mathrm{b} 1}$} & \multirow[t]{2}{*}{ sh } \\
\hline $\begin{array}{r}\text { енетичні } \\
\text { горизонти } \\
\end{array}$ & $\stackrel{0}{I}$ & है & $\cong$ & $\frac{+}{a}$ & & & & & & & & & & & \\
\hline либин , м & $\tilde{0}$ & o & $\stackrel{\infty}{0}$ & $\Rightarrow$ & 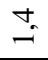 & $\stackrel{d}{i}$ & $\stackrel{n}{i}$ & $\stackrel{m}{m}$ & $\hat{m}$ & $\vec{\nabla}$ & $\begin{array}{l}0 \\
\dot{\nabla}\end{array}$ & $n$ & iे & ñ & $\stackrel{?}{\sim}$ \\
\hline $\begin{array}{c}\text { міст гумусу, } \\
\%\end{array}$ & a. & $\stackrel{n}{\circ}$ & $\stackrel{+}{0}$ & $\frac{1}{0}$ & $n$ & ñ & $\frac{9}{0}$ & ป̂ & \begin{tabular}{l}
$\infty$ \\
\multirow{2}{0}{} \\
0
\end{tabular} & $\frac{2}{0}$ & $\tilde{n}$ & $\dot{0}$ & ñ. & 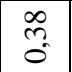 & $\stackrel{n}{5}$ \\
\hline $\begin{array}{c}\text { міст } \\
\text { к } \quad \text { рбон тів, \% } \\
\end{array}$ & $\frac{0}{2}$ & ñ & $=$ & $\tilde{n}$ & $\stackrel{2}{\circ}$ & in & $\stackrel{n}{=}$ & 范 & $\frac{1}{0}$ & 8 & ڤn & $\pi$ & gे & $\frac{ \pm}{0}$ & 8 \\
\hline
\end{tabular}

блиця 3

міст гумусу т к рбон тів у різновікових відкл д х розрізу м нь

\begin{tabular}{|c|c|c|c|c|c|c|c|c|c|c|c|c|}
\hline $\begin{array}{l}\text { тр тигр фічні } \\
\text { горизонти }\end{array}$ & \multicolumn{6}{|c|}{ hl } & \multirow[t]{2}{*}{$\mathbf{d f}_{\mathrm{c}}$} & \multicolumn{3}{|c|}{$\mathbf{d f}_{\mathrm{b}}$} & \multirow{2}{*}{\multicolumn{2}{|c|}{ bg }} \\
\hline $\begin{array}{r}\text { енетичні } \\
\text { горизонти }\end{array}$ & Нд. тех. & тех. & орн. & $\mathrm{Hp}(\mathrm{e})$ & $\mathrm{Ph}(\mathrm{i})$ & $\mathrm{Pk}+\mathrm{pc}$ & & $\mathrm{Hk}$ & Phk & $\mathrm{Pk}$ & & \\
\hline либин , м & 0,1 & 0,5 & 0,8 & 1,2 & 1,5 & 1,8 & 2,2 & 2,7 & 3,2 & 3,5 & 3,8 & 5,2 \\
\hline міст гумусу, \% & 1,78 & 1,71 & 1,85 & 0,95 & 0,4 & 0,98 & 0,82 & 0,56 & 0,84 & 0,58 & 0,69 & 0,35 \\
\hline 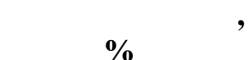 & 0,25 & 0,4 & 0,53 & 0,62 & 0,19 & 1,62 & 1,57 & 2,98 & 3,24 & 4,91 & 3,9 & 3,24 \\
\hline
\end{tabular}


міст гумусу т к рбон тів у різновікових відкл д х розрізу езіменне

\begin{tabular}{|c|c|c|c|c|c|c|c|c|c|c|c|c|c|c|c|c|c|c|c|}
\hline $\begin{array}{c}\text { тр тигр - } \\
\text { фічні }\end{array}$ & \multicolumn{3}{|c|}{ hl } & df & \multicolumn{2}{|c|}{ bg } & \multirow[t]{2}{*}{ vt } & \multirow[t]{2}{*}{$\mathbf{p l}_{\mathbf{c}}$} & \multicolumn{2}{|c|}{$\mathbf{p l}_{\mathrm{b}}$} & \multirow{2}{*}{$\begin{array}{l}\text { ts } \\
\frac{y}{a}\end{array}$} & \multicolumn{2}{|c|}{$\mathbf{k d}_{\mathbf{b 1}}$} & \multicolumn{2}{|c|}{$\mathbf{k d}_{\mathrm{a}}$} & \multicolumn{4}{|c|}{ dn } \\
\hline $\begin{array}{r}\text { енетичні } \\
\text { горизонти }\end{array}$ & $I$ & 옴 & $\frac{\stackrel{a}{+}}{\frac{1}{a}}$ & $\frac{x}{2}$ & & & & & 오 & $\frac{2}{\vec{L}}$ & & 至 & 디 & $\pm \underset{50}{\stackrel{0}{0}}$ & ED & & & & \\
\hline либин , м & $\overrightarrow{0}$ & $\hat{n}$ & $\stackrel{0}{0}$ & $\hat{\sigma}$ & $\stackrel{\sim}{-}$ & $\because$ & $\underline{G}$ & d & $\tilde{n}$ & i & $\hat{\mathrm{a}}$ & $\vec{m}$ & $\dot{m}$ & $\ddot{m}$ & $\stackrel{\infty}{m}$ & $\vec{f}$ & $\stackrel{F}{f}$ & $\stackrel{\sim}{n}$ & $\stackrel{+}{\dot{n}}$ \\
\hline $\begin{array}{c}\text { міст } \\
\text { гумусу, \% }\end{array}$ & $\stackrel{i}{i}$ & त̂ & $\stackrel{\infty}{\stackrel{\infty}{\sim}}$ & $\frac{n}{0}$ & $\ddot{0}$ & $\stackrel{2}{0}$ & $\ddot{0}$ & $\tilde{n}$ & ర్ & 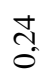 & $\frac{ \pm}{0}$ & m. & 0 & $\frac{9}{0}$ & $\begin{array}{l}8 \\
0 \\
0\end{array}$ & $\begin{array}{l}8 \\
0 \\
0\end{array}$ & $\stackrel{\sigma}{0}$ & Oे. & ô. \\
\hline $\begin{array}{cc} & \text { міст } \\
\text { к } & \text { рбон тів, } \\
\% & \text { тів }\end{array}$ & $\begin{array}{l}\text { m. } \\
0\end{array}$ & $\begin{array}{l}n \\
\tilde{0} \\
0\end{array}$ & 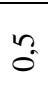 & $\stackrel{\dot{m}}{m}$ & $\frac{2}{i}$ & $\hat{n}$ & $\begin{array}{l}\hat{\sigma} \\
0\end{array}$ & $\stackrel{g}{\sim}$ & $\overrightarrow{\widetilde{N}}$ & ָ̇ & $\frac{n}{0}$ & $\stackrel{8}{0}$ & $\stackrel{0}{0}$ & ㅇ. & $\begin{array}{l}8 \\
0 \\
0\end{array}$ & $\hat{0}$ & ¿ & $\stackrel{n}{0}$ & $\overline{0}$ \\
\hline
\end{tabular}
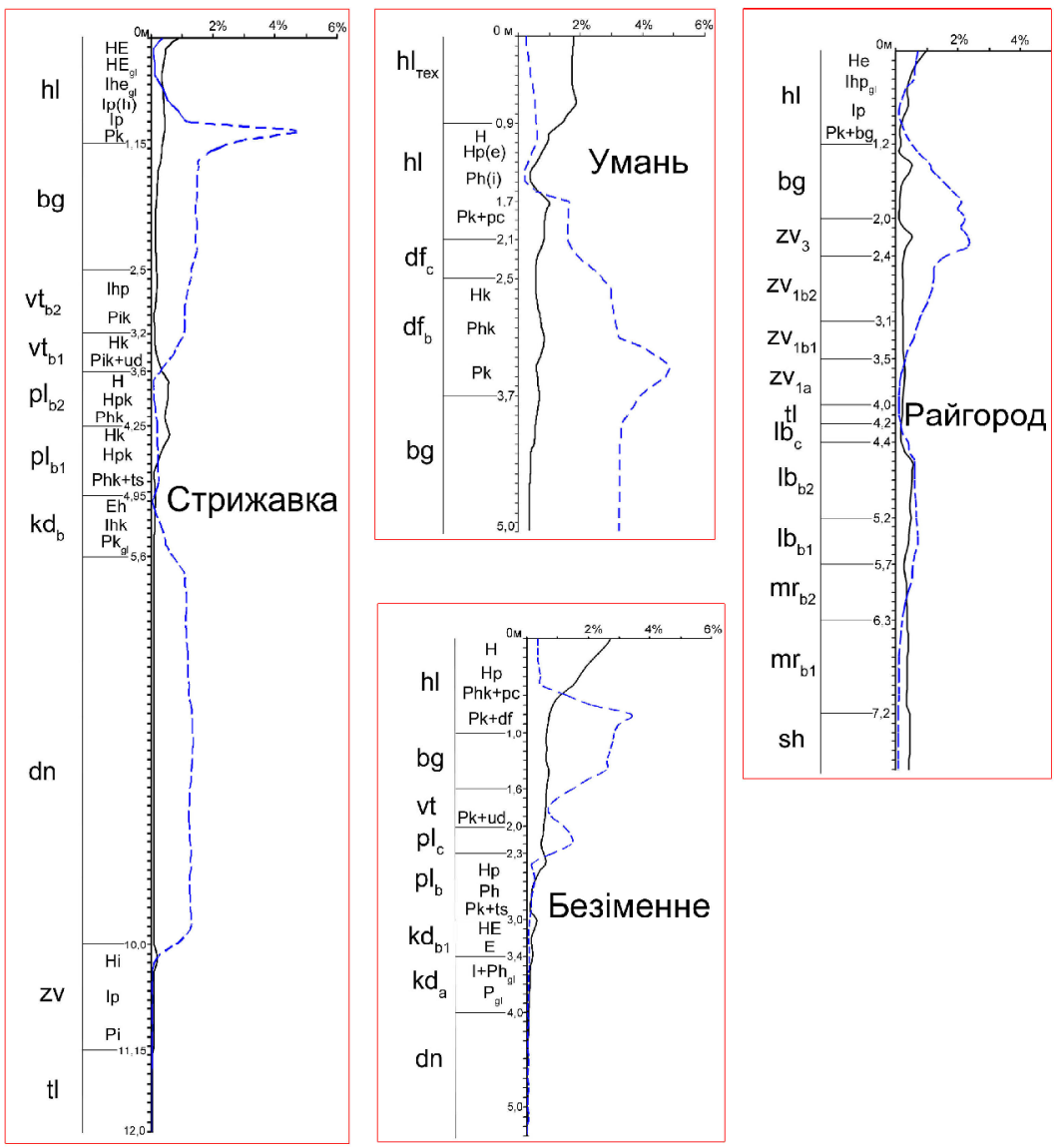

ис. 5. р фіки розподілу т вмісту гумусу (-) і к рбон тів (---) у плейстоценових відкл д х розрізів триж вк, м нь, йгород і езіменне. 
підст ві отрим них д них побудов но гр фіки розподілу й вмісту гумусу т к рбон тів у різновікових четвертинних відкл д х досліджених розрізів (див. рис. 5) i проведено п леогеогр фічні інтерпрет ції. окрем, отрим ні результ ти щодо вмісту орг нічних речовин у плейстоценових горизонт х ереднього обужжя д ють підст ви стверджув ти, що д внє гумусоутворення в меж х окремих горизонтів, як і суч сне, підпорядков не 3 кон м широтної геогр фічної зон льності, оскільки скл д і будов орг нічних речовин змінюється з лежно від генетичних типів грунтів, які формуються в різних фізико-геогр фічних умов х.

трим ні результ ти підтверджують д ні про вищий вміст гумусу в горизонт х викопних грунтів $(0,1-0,84 \%)$ порівняно з лесовими $(0,04-0,19 \%)$, що свідчить про формув ння грунтових горизонтів у тепліших і вологіших умов х, сприятливих для процесів грунтоутворення.
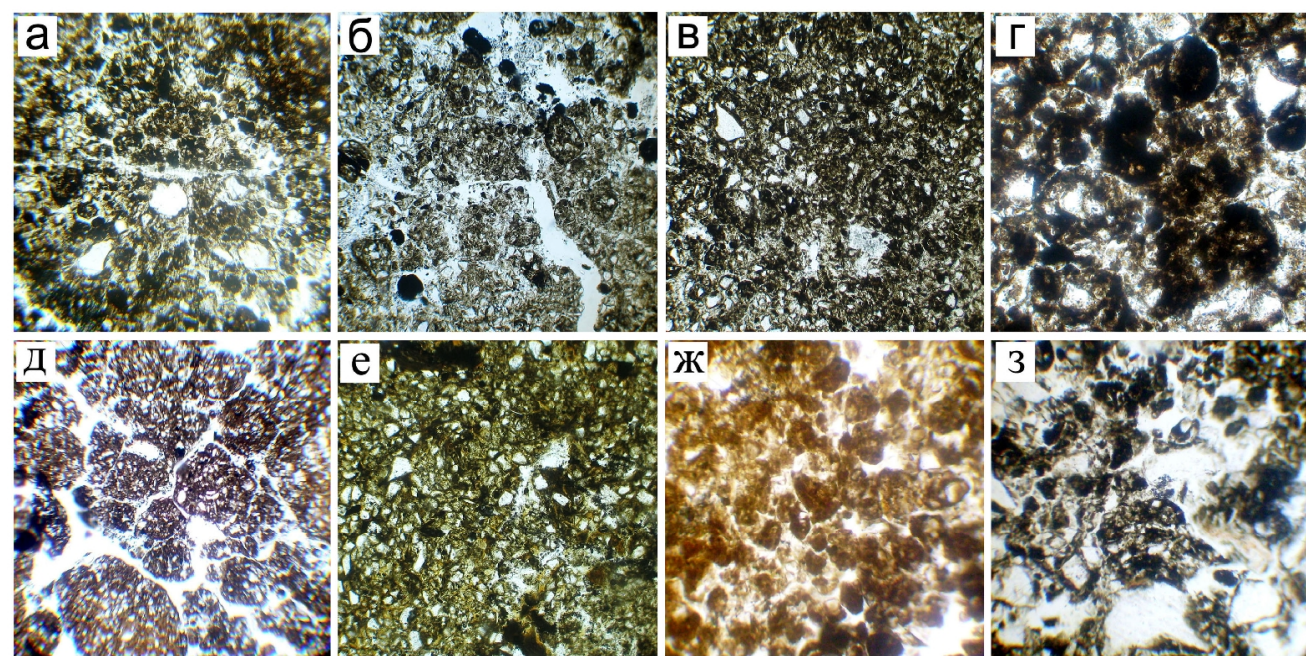

ис. 6. ікроморфологічні озн ки біогенно- кумулятивних процесів у викопних плейстоценових грунт х ереднього обужжя:

- скл дні мікро грег ти до четвертого порядку, розділені сіткою звивистих пор, у гумусовому горизонті чорнозему буроземоподібного ( $\mathrm{pl}_{\mathrm{b} 2}$; триж вк ) (зб. 80); б - скл дн мікро грегов ність чорнозему буроземоподібного ( $\mathrm{pl}_{\mathrm{b} 2}$; кушинці) (зб. 100); в - мікробудов гумусового горизонту лучного чорнозему $\left(\mathrm{pl}_{\mathrm{b} 1} ;\right.$ кушинці) (зб. 100); г - гумус ско гульов ний у вигляді гумонів у гумусовому горизонті лучного чорнозему ( $\mathrm{pl}_{\mathrm{b} 1}$; кушинці) (зб. 400); д - копроліти дощових червів у вигляді скл дних мікро грег тів, розділених сіткою звивистих пор, у гумусовому горизонті чорнозему лучного ( $\mathrm{pl}_{\mathrm{b} 1} ;$ ервом йськ) (зб. 70); е - диспергов ний гумус в ілюві льному горизонті сірого опідзоленого грунту $\left(\mathrm{kd}_{\mathrm{b} 1} ; \quad\right.$ кушинці) (зб. 100); ж - темно-бурий гумус ско гульов ний в округлі мікро грег ти першого-другого порядку в п лево-бурому степовому грунті ( $\mathrm{df}_{\mathrm{c}} ;$ м нь) (зб. 140); з - з лізисто-глинисті мікро грег ти лучно-коричневого чорноземоподібного грунту $\left(\mathrm{lb}_{\mathrm{b} 2} ; \quad\right.$ нкр тове 1$)(36.70$, нік. ). всіх фото нік. .

ро збереження якісних особливостей орг нічних речовин і підвищення гумусов ності м си у викопних грунт х плейстоцену дофінівського, прилуцького, к йд цького т лубенського віку свідч ть т кож д ні мікроморфологічних досліджень [7]. окрем , результ ти проведених п леопедологічних, у тому числі мікроморфологічних досліджень з ді гностики д вніх грунтоутворюв льних процесів у викопних плейстоценових 
грунт х ереднього обужжя, з свідчують яскр ві озн ки біогенно- кумулятивних процесів у вигляді добре вир женої скл дної мікро грегов ності м си 3 грег т ми високого порядку, темного з б рвлення гумусово-глинистої пл зми, ско гульв ного гумусу типу муль, розвиненої сітки звивистих пор тощо (див. рис. 6). собливо яскр во озн ки гумусон копичення виявляються у чорноземних прилуцьких грунт х.

лес х же розвиток грунтоутворюв льних процесів лімітов ний швидкістю седимент ції т холодними темпер турними умов ми. к н слідок, у мікроморфологічній будові типових лесів нем скл дної мікро грегов ності м си, н томість виявляються інші озн ки: пухке скл дення м си, пилув то-пл змов елемент рн мікробудов , освітлен к рбон тно-глинист пл зм , зерн первинних мінер лів сумірні з лесовими ч сточк ми, окут ні прозорими к рбон тно-глинистими плівк ми т оболонк ми (рис. 7). еред лесових горизонтів з доволі високими пок зник ми вмісту гумусу $(0,3-0,7 \%)$ виділяються бузькі леси (див. т бл. 1-4, рис. 5), що можн пояснити порівняно нетрив лим ч сом їхньої фосиліз ції т впливом суч сних біогеннокумулятивних процесів.

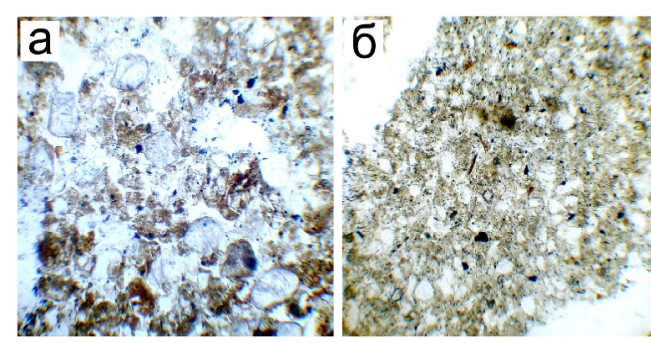

ис. 7.

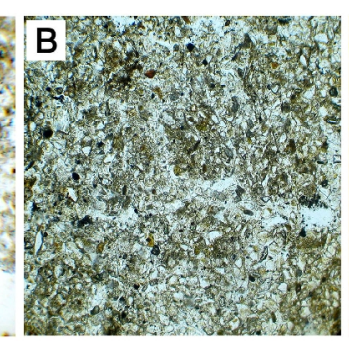

ереднього обужжя:

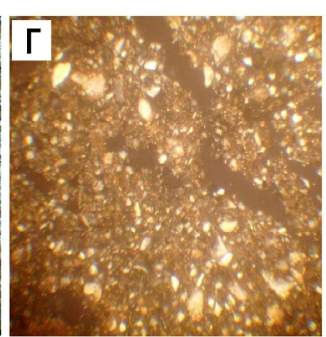

- мікробудов причорноморського лесу: сумірність лесових ч сточок з зерн ми первинних мінер лів, крупні крист ли к льциту ( ервом йськ) (зб. 140, нік. ); б - зерн первинних мінер лів сумірні з лесовими ч сточк ми, окут ні к рбон тно-глинистими плівк ми ( езіменне) (зб. 140, нік. ); в - пухк мікробудов дніпровського лесу ( кушинці) (зб. 100, нік. ); г - пилув то-пл змов мікробудов уд йського лесу; м с, просочен мікрокрист лічним к льцитом ( оробчине) (зб. 70, нік. +).

плейстоценових грунт х ереднього обужжя, що подібні до генетичних типів суч сних грунтів субборе льних обл стей, простежуються н логічні з кономірності в розподілі гумусових речовин по профілю. окрем, у викопних чорноземоподібних грунт х лубенського, прилуцького т дофінівського ч сів вміст гумусу знижується поступово вниз по профілю (див. рис. 5). дерново-підзолистих, бурих і сірих опідзолених грунт х (р нні оптимуми з в дівського т к йд цького ч сів) кількість гумусу різко зменшується з глибиною, спостеріг ють озн ки перерозподілу т ілювіюв ння гумусу по профілю. роцеси опідзолення т ілювіюв ння т кож чітко ді гностують з допомогою мікроморфологічного н лізу у вигляді різном нітних новоутворень полиніту (див. рис. 8).

p нньоплейстоценових грунт х (лубенських, м ртоноських, широкинських) вміст гумусу знижується вниз по профілю поступово, одн к кількісні пок зники нижчі порівняно з чорноземними грунт ми середнього-пізнього плейстоцену що, ймовірно, пов'яз не з його мінер ліз цією т переходом у інші форми хімічних сполук у процесі фосиліз ції. 


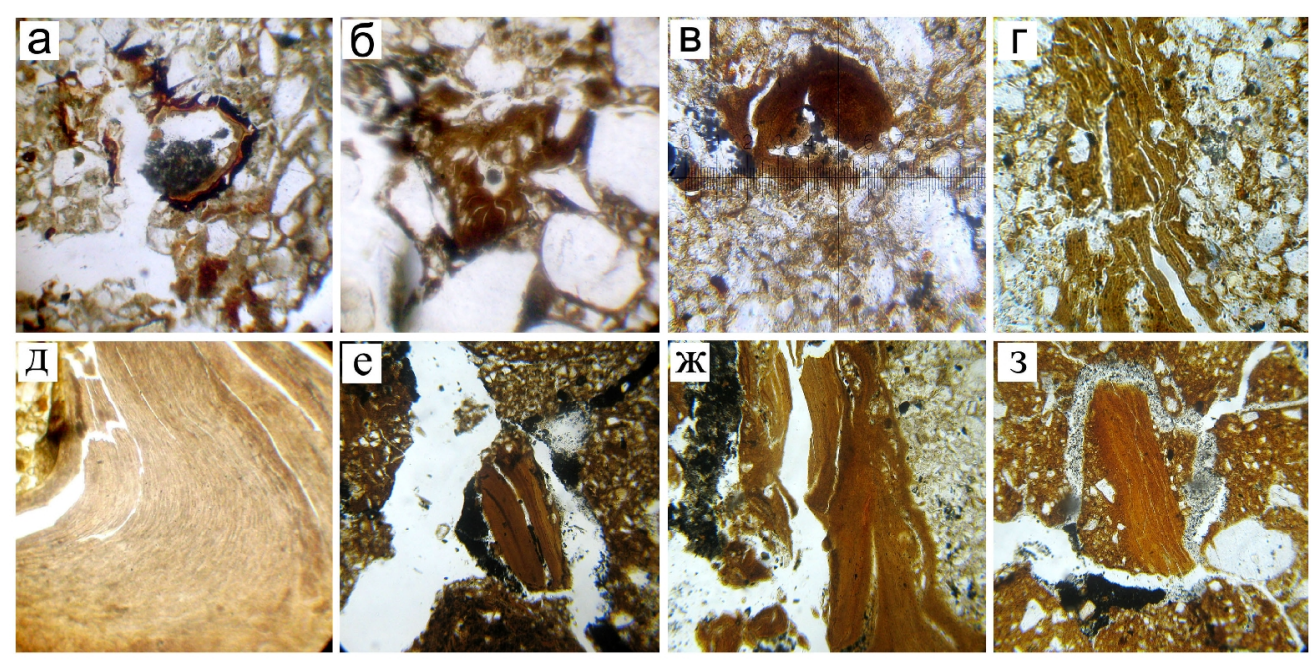

ис. 8. ікроморфологічні озн ки ілюві льно- кумулятивних процесів у викопних грунт х ереднього обужжя:

- м нг ново-з лізисто-глинистий н тік полиніту н стінк х пори дерново-глейового грунту $\left(\mathrm{kd}_{\mathrm{a}}\right.$; езіменне) (зб. 70); б - темно-бурий н тік полиніту в порі дерново-підзолистого грунту $\left(\mathrm{kd}_{\mathrm{b} 1}\right.$; езіменне) (зб. 140$)$; в - лускув тий н тік коломорфних глин в бурому лісовому опідзоленому грунті $\left(\mathrm{kd}_{\mathrm{b} 1}\right.$; триж вк ) (зб. 400); г - н тік коломорфних глин в ілюві льному горизонті сірого опідзоленого грунту $\left(\mathrm{kd}_{\mathrm{b} 1} ;\right.$ кушинці) (зб. 400); д - н тік коломорфних глин 3 вкр пленнями ч сточок грубих глин т гумусу в ілюві льному горизонті дерново-підзолистого люві льного грунту $\left(\mathrm{kd}_{\mathrm{bl}}\right.$; еджибіж) (зб. 140); е - 3 лізисто-глинистий лускув тий н тік в червонув то-бурому лісовому грунті ( $\mathrm{zv}_{\mathrm{b} 1}$; йгород) (зб. 100); ж - н тік полиніту в порі тилігульського м тері лу (вплив процесів з в дівського грунтоутворення; йгород) (зб. 100); 3 - 3 лізисто-глинистий н тік полиніту в порі червонув то-коричневого лучного грунту (sh; игород) (зб. 100). всіх фото нік. .

одноч с м йже в усіх досліджених лесових горизонт х порівняно з грунтовими фіксують вищі пок зники к рбон тності. инятком є вип дки, коли м тері л лесів ун слідок ді генетичних змін вилужений в умов х більш гумідного клім ту протягом н ступних п леогеогр фічних ет пів (тилігульський лес у розрізі йгород) бо сформув вся у зниженнях рельєфу. лесових горизонт х к рбон ти перев жно рівномірно розподілені по товщі, концентруються у вигляді плям, вицвітів, міцелію, трубочок, рідше дрібних конкрецій, дутиків, жур вчиків т інших форм. мікроморфології це підтверджене просоченням т цемент цією м си мікрокрист лічним К льцитом (див. рис. 7, г), різном нітними к рбон тними новоутвореннями.

грунтових горизонт х вміст к рбон тів порівняно нижчий; до того ж, окремі грунтоутворюв льні процеси сприяють перерозподілу їх по профілю. окрем, у лісових чи лучно-лісових грунт х, які формув лись 3 умов підвищеного зволоження, виявляється вилуженість м си від к рбон тів, особливо у верхній ч стині профілю. илужені від к рбон тів грунти поч ткової ст дії т р ннього оптимуму з в дівського т к йд цького ч сів, лучно-чорноземні грунти прилуцького ч су, верхні ч стини профілів суч сних грунтів. 
рунти степового генезису більш к рбон тні, в нижній ч стині їхніх профілів чітко виділяється Pk горизонт у вигляді т к зв ного к рбон тного ілювію $\left(\mathrm{lb}_{\mathrm{b} 2}, \mathrm{pl}_{\mathrm{b} 2}, \mathrm{pl}_{\mathrm{c}}\right.$, $\mathrm{df}_{\mathrm{b}}$, усі досліджені голоценові грунти). мікроморфології процеси к рбон тиз ції простежуються у викопних плейстоценових грунт х 3 різном нітними форм ми к рбон тних новоутворень (рис. 9). Йвищий рівень к рбон тності серед верхньоплейстоценових грунтових горизонтів вл стивий вит чівським грунтовим утворенням (пон д $1 \%)$.
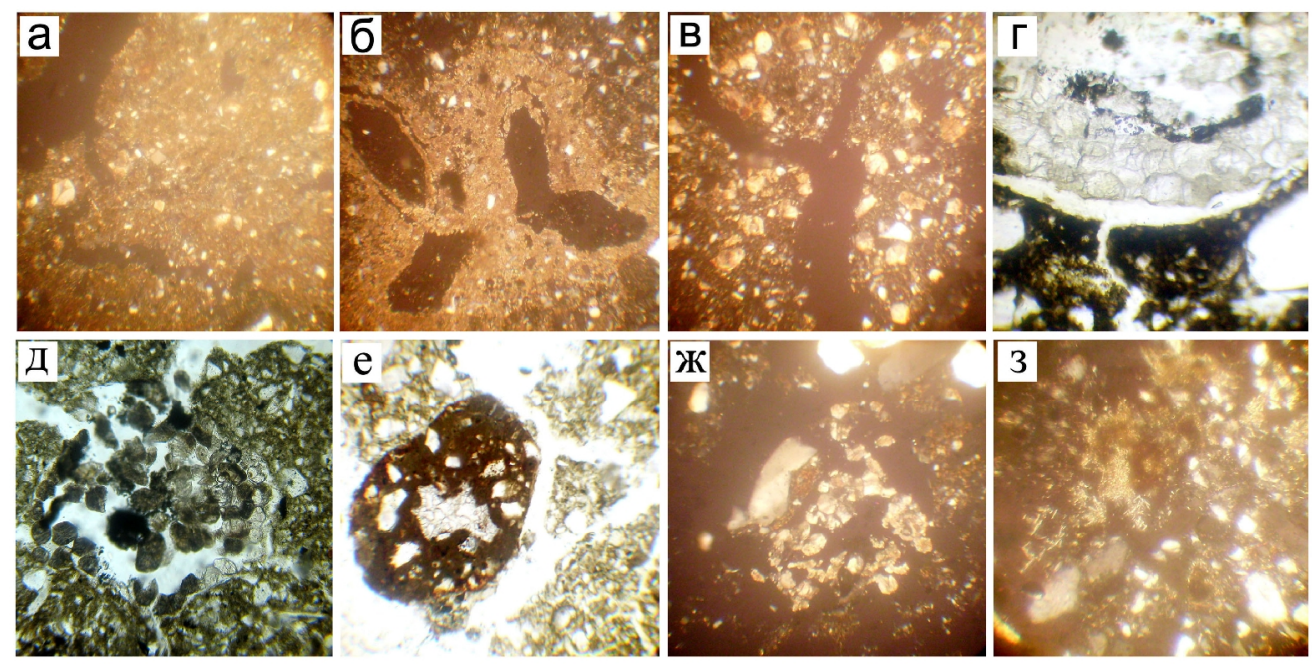

ис. 9. ікроморфологічні озн ки процесів к рбон тиз ції

у викопних плейстоценових грунт $\mathrm{x}$ ереднього обужжя:

- цемент ція пл зми мікрокрист лічним к льцитом в Pk горизонті дофінівського чорноземоподібного грунту ( м нь) (3б. 70, нік. +); б - мікрокрист лічний к льцит виокремлюється н вколо пор в нижній ч стині бурого грунту ( $\mathrm{vt}_{\mathrm{b} 2}$; еджибіж) (зб. 70, нік. +); в - мікрокрист лічний к льцит просочує пл зму злитих блоків темно-бурого грунту, дрібнокрист лічний к льцит у вигляді окремих крупних зерен ( $\mathrm{vt}_{\mathrm{b} 1}$; оробчине) (зб. 70, нік. +); г - фр гмент конкреції з дрібнокрист лічного к льциту в порі бурого грунту ( $\mathrm{vt}_{\mathrm{b} 2} ;$ ись) (зб. 140, нік. $)$; д - скупчення дрібнокрист лічного к льциту в порі червонув то-бурого грунту $\left(\mathrm{lb}_{\mathrm{c}} ;\right.$ йгород) (зб. 100, нік. $)$; e - новоутворення дрібнокрист лічного к льциту в середині 3 лізистого мікроорштейну в червонув то-бурому люві льному грунті ( $\mathrm{zv}_{3} ;$ еджибіж) (зб. 70, нік. $)$; ж - дрібнокрист лічний к льцит у вигляді л нцюжків у порі-к н лі темно-бурого грунту (vt $\mathrm{b}_{\mathrm{b}} ;$ ись) (зб. 70, нік. +); 3 - голч стий к льцит (люблініт) в пл змі Phk горизонту лучно-чорноземного грунту $\left(\mathrm{pl}_{\mathrm{b}} ;\right.$ езіменне) (зб. 70, нік. +).

p нньоплейстоценових грунт х поряд з міцелярними т борошнистими форм ми к рбон тів тр пляються доволі крупні конкреції т стяжіння. і новоутворення ч сто приурочені до тріщин, утворюють цілі конкреційні горизонти. дн К вміст к рбон тів у грунт х широкинського ч су (лучні червонув то-коричневі) т р ннього оптимуму м ртоноського (червонув то-бурі лісові й н півгідроморфні) незн чний, що пояснюють іхнім вимив нням у нижні ч стини профілів і ді генетичним перетворенням первинних к рбон тів у кремнієво-к рбон тні т к рбон тні конкреції й стяжіння під впливом грунтових вод. одноч с вищі пок зники к рбон тності лубенських грунтів свідч ть 
про посушливіші природні умови ч су їхнього формув ння порівняно з широкинськими т м ртоноськими грунт ми.

озподіл к рбон тів по профілю грунтової світи т кож допом г є відновити хронологію природних процесів протягом певного п леогеогр фічного ет пу, уточнити ст дії розвитку і виявити послідовність формув ння грунтів. прикл д, порівняно 3 грунт ми поч ткової ст дії $\left(\mathrm{zv}_{\mathrm{a}}\right)$ т $\mathrm{p}$ нніх оптимумів $\left(\mathrm{zv}_{1 \mathrm{bl}}, \mathrm{mr}_{\mathrm{b} 1}\right)$ підвищений вміст к рбон тів простежується у грунт х пізніх оптимумів $\left(\mathrm{zv}_{1 \mathrm{~b} 2}, \mathrm{mr}_{\mathrm{b} 2}\right)$. я особливість, згідно з особливостями кл сів л ндш фтно-геохімічних систем, свідчить про формув ння грунтів пізніх оптимумів у сухіших умов х. исокий вміст к рбон тів $є$ в грунт $\mathrm{x}$ 3 верш льних ст дій, зокрем в грунті $\mathrm{Zv}_{3}$ розрізу йгород $\mathrm{T}$ грунті $\mathrm{pl}_{\mathrm{c}}$ розрізу езіменне. цих вип дк х високий ступінь к рбон тності пояснюють як вл сне умов ми грунтоутворення, які були н ближені до степових, сухостепових, теплих т сухих, т к і вторинним ок рбон ченням грунтів з верш льної ст дії протягом н ступних холодних і сухих лесових ет пів (ді генез відкл дів).

тже, отрим ні н літичні д ні щодо вмісту й розподілу гумусу і к рбон тів у плейстоценових відкл д х н д ють цінну дод ткову інформ цію про п леогеогр фічні умови ч су їхнього формув ння. ідвищений вміст гумусу в горизонт х викопних грунтів свідчить про сприятливіші умови для процесів грунтоутворення (зокрем , біогенно- кумулятивних) порівняно з лесовими. йвищий вміст гумусу в чорноземних грунт х лубенського, прилуцького т дофінівського віку $(0,5-0,85 \%)$. езн чний вміст гумусу у р нньоплейстоценових грунт $\mathrm{x}$, що, ймовірно, пов'яз не $з$ н ступною його мінер ліз цією т переходом у інші форми хімічних сполук під ч с фосиліз ції.

p ктер розподілу гумусових речовин по профілю визн ч є генетичні типи грунтів: у чорноземоподібних вміст гумусу знижується поступово вниз по профілю; у підзолистих фіксують різке п діння з глибиною, спостеріг ють перерозподіл по генетичних горизонт х.

ідвищений вміст первинних к рбон тів вл стивий лесовим горизонт м і з свідчує більш ридні умови ч су їхнього формув ння. ля лесів х р ктерний рівномірний розподіл к рбон тів у товщі, форми у вигляді плям, вицвітів, міцелію, трубочок, рідше дрібних конкрецій, дутиків i жур вчиків. грунт х вміст к рбон тів порівняно нижчий (особливо в лісових), виділяеться горизонт к рбон тного ілювію. йбільш к рбон тні вит чівські грунти. нньоплейстоценові грунти перев жно вилужені від к рбон тів, одн к поряд із борошнистими т міцелярними форм ми к рбон тів у них ч сто тр пляються цілі горизонти крупних к рбон тних конкрецій т стяжінь.

перспективі було б цік во отрим ти д ні щодо групового скл ду гумусу у викопних грунт $\mathrm{x}$ ереднього обужжя, зокрем, співвідношення між гуміновими т фульвокислот ми, т кож гумін ми. е н д ло б змогу порівняти особливості будови орг нічних речовин викопних грунтів 3 н логічними генетичних типів суч сних грунтів т отрим ти нові д ні щодо п леогеогр фічних умов ч су їхнього формув ння. 


\section{СПИСОК ВИКОРИСТАНОЇ ЛІТЕРАТУРИ}

1. луш нков . . рг ническое вещество погребенных почв, новейших отложений и его п леогеогр фическое зн чение: втореф. дис. н соиск ние ученой степени к ндид т геогр фических н ук: специ льность 11.690 “ бщ я физическ я геогр фия" / . . луш нков . - ., 1972. -25 с.

2. луш нков . . леопедогенез и природн я сред осточной вропы в плейстоцене / . . луш нков .- моленск; оскв : гент , 2008. - 348 с.

3. рунты. етоды л бор торного определения содерж ния орг нических веществ. 23740-79. - . : осуд рственный ст нд рт оюз , 1979.-22 с.

4. ерг чев . . рг ническое вещество ископ емых почв / . . ерг чев , . . ыкин .- овосибирск : ук . иб. отделение, 1988. - 128 с.

5. ерг чев . . умусов я п мять почв: уровни ее проявления и информ тивность при реконструкции п леоклим тов прошлого / . . ерг чев // зменения клим т , почвы и окруж ющ я сред : тери лы еждун родного н учного семин p.- елгород : $\quad$ 2009. - .23-25.

6. орошкевич . . леогеогр фічні умови в ередньому обужжі 3 д ними п леопедологічного дослідження розрізу плейстоценових відкл дів біля c. йгород / . . орошкевич // із. геогр фія т геоморфологія. - 2010. ип. 4 (61). - . 205-215.

7. орошкевич . . міни природних умов у плейстоцені н території ереднього обужжя з д ними вивчення викопних грунтів / . . орошкевич , . . твіїшин // кр. геогр. журн., 2012. - № 4. - . 23-30.

8. орошкевич . . і гностик грунтоутворюв льних процесів у викопних плейстоценових грунт х 3 д ними мікроморфологічного н лізу / . . орошкевич, . . твіїшин // ук. вісник ернів. ун-ту. іологія ( іологічні системи). 2012. - . $4(2)$. - ип. 1. - . .162-166.

9. твїшин . . леогеогр фічні умови в окремі теплі ет пи плейстоцену 3 д ними п леопедологічного дослідження розрізу біля с. триж вк / . . твіїшин , . . орошкевич // ук. 3 п. інн. пед. ун-ту ім. . оцюбинського. ер. геогр фія. - 2010. - ип. 20. - . 5-16.

10. твї̈шин . . лейстоценові викопні грунти ереднього обужжя 3 результ т ми дослідження нових розрізів / . . твіїшин , . . рм зиненко, . . орошкевич // ук. вісник ернів. ун-ту. еогр фія. - 2009. - ип. 458. $.41-45$.

11. етодик п леопедологических исследов ний / [ . . еклич, . . твиишин , . . едведев и др.]. - иев : ук. думк , 1979. - 272 с.

12. тр тигр фическ я схем четвертичных отложений кр ины / . . еклич, . . иренко, . . твиишин и др. // тр тигр фические схемы ф нерозоя и докембрия кр ины. - иев : оскомитет геологии кр ины, 1993. -40 с. -4 т бл.

$$
\begin{gathered}
m \text { ття:н дійшл до ред кцї 11.04.2013 } \\
\text { доопр цьов н 14.05.2013 } \\
\text { прийнят до друку 17.06.2013 }
\end{gathered}
$$




\title{
ORGANIC MATTERS AND CARBONATES IN FOSSIL PLEISTOCENE SOILS AND LOESS OF MIDDLE POBUZHYA REGION AND THEIR PALEOGEOGRAPHICAL VALUE
}

\author{
Sergiy Doroshkevich ${ }^{1}$, Galyna Zadvernyuk ${ }^{2}$ \\ ${ }^{1}$ Institute of Geography of National Academy of Sciences of Ukraine, \\ Volodymyrska St., 44, UA-01034, Kyiv, Ukraine \\ ${ }^{2}$ State Institution "Institute of Environmental Geochemistry of National Academy of Sciences of Ukraine”, \\ Acad. Palladina Ave., 34a, UA - 03680, Kyiv, Ukraine
}

Data on content of organic matters and carbonates in fossil of Pleistocene soils and loesses of four new cuts of quaternary deposits in the territory of Middle Pobuzhya region are given. The value of the study on content and distributing of humus and carbonates in of different age horizons of quaternary deposits for the paleogeography reconstructions of natural conditions of formation time of fossil of Pleistocene soils and loesses is ascertained.

Key words: paleogeography, Pleistocene, fossil soils, loess, organic matters, carbonates.

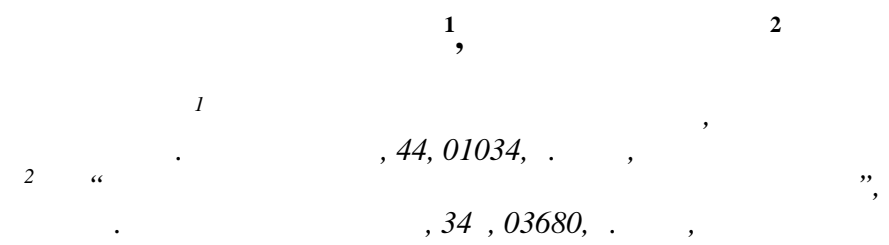

риведено д нные относительно содерж ния орг нического веществ и к рбон тов в ископ емых плейстоценовых почв х и лесс х четырех новых $p$ зрезов четвертичных отложений территории реднего обужья. ст новлено зн чение исследов ний содерж ния и р спределения гумус и к рбон тов в $\mathrm{p}$ зновозр стных горизонт х четвертичных отложений для п леогеогр фических реконструкций природных условий времени обр зов ния ископ емых плейстоценовых почв и лессов.

лючевые слов : п леогеогр фия, плейстоцен, ископ емые почвы, лессы, орг ническое вещество, к рбон ты. 